\title{
中学田径体育训练改革措施
}

\author{
刘洋 \\ 江西育华学校 \\ DOI:10.32629/er.v3i7.2953
}

\begin{abstract}
[摘 要] 中学体育教学质量直接影响学生整体的身体素质, 合理加强中学体育教学能够有效促进中学 学生身心健康发展, 在一定程度上提高了学生的综合素质,使教学效果得到最大化的提升。做好田径体育 训练开展, 则能够为学生身体素质的提升提供借鉴, 能够让学生的身体素质得到提高。本文就中学田径体 育训练改革路径进行探索,希望可以为中学田径教学的优化提供借鉴。
\end{abstract}

[关键词] 田径体育; 体育训练; 训练改革

作为中学体育教学的主要教学内 容之一, 田径体育教学是任课教师的关 注的重点, 也是学生体质训练内容的重 要组成部分。但在实际的教学过程中, 部分任课教师往往以篮球、足球等体育 训练作为教学工作的重心, 相比之下, 田径体育训练的的重视程度偏低, 采取 的训练方式也过于单一, 实际的训练过 程趣味性不高, 导致学生对于田径体育 训练的积极性不高, 不利于学生的健康 全面成长。

\section{1 中学田径体育训练改革意义}

1. 1增强学生体质

在中学体育训练的诸多项目中, 田 径体育训练具有重要的影响作用, 如果 学校体育管理小组能够加强田径体育 训练工作的重视程度以及执行能力, 同 时以人才培养需要以及中学体育教学 目标作为努力的最终结果, 选择适合学 生的训练方式, 能够有效调动学生对体 育训练项目的积极性, 更好地融入其 中。不仅能够掌握田径体育训练的技能,

党。只有将党建平台与师德师风的建设 进行融合, 根据实际的工作性质, 做好教 学制度的完善、教学模式的创新, 才能达 到良好的教学效果。

\section{3 结束语}

综上所述, 对于民办高校来说, 要想 实现基础的育人目标, 就要保证办学方 向正确, 立德树人, 并且建立将党员教师
而且能够得到充足的锻炼空间, 增强学 生体质, 有助于学生未来的体育运动和 训练发展。

\section{2 养成锻炼习惯}

在实际进行体育训练的过程中, 任 课教师应当结合学生的实际情况以及学 校环境, 科学合理的制定教学目标以及 训练要求, 以学生为中心, 从身体素质和 兴趣爱好两个角度出发, 制定最终的田 径体育训练方案。除此之外, 为让学生能 够快速理解并掌握训练要点以及训练技 巧, 任课教师还应当结合实际教学情况 加强训练方法指导, 有效培养学生形成 良好的体育锻炼习惯, 保证学生能够更 好的融入体育训练当中来, 进一步提高 学生整体的训练质量。

\section{3 提高教学效果}

为让学生快速掌握田径体育训练技 巧, 任课教师在实际训练过程中, 应结合 学生的实际情况选择合理的措施加强学 生的训练工作, 从而使学生理解并熟练 掌握田径体育训练的技巧。进而有效提
高学生对田径体育训练的学习兴趣, 更 好的融入到体育训练中来。另外, 任课教 师应当把握训练过程中的每个要点, 帮 助学生培养良好的锻炼习惯, 树立终身 体育锻炼的思想观念, 有效提高中学田 径体育训练效果。

\section{2 中学田径体育训练改革措施}

2. 1科学选择训练项目

盲目选择训练项目是导致田径训练 现状的重要原因, 田径训练项目的选择 受地区经济条件、体育教育发展程度等 因素的影响, 缺乏固定统一的选择标准, 不同地区选择的田径训练项目往往差异 较大, 进而可能会导致任课教师中学田 径体育训练项目选择不当现象出现。因 此, 科学选择训练项目应当成为中学田 径训练改革措施的重要内容, 其标准制 定应当明确到实际操作层面, 不必各地 区训练项目选择标准一致, 但必须结合 当地学生的具体情况科学选择合理的田 径体育训练项目, 同时以该地区体育事 业未来发展方向为制定基础, 必须坚持
培养成教学骨干, 将优秀教师培养成为 党员的双培养模式。民办高校需要引入 这种教学模式, 为社会培养出更多高素 质的人才, 逐步完善育人体系的建设。

\section{[参考文献]}

[1]熊斌,张文通,木笑波.民办高校 教师队伍 “双培养” 党组建设平台探析 [J].继续教育,2017,31(09):54-56.
[2]王姝欣,朱金璐.关于民办高校党 建工作形成模式的研究 $[J]$. 决策与信息 旬刊,2015,(05):31-32.

[3]王艳君.党建工作引领下民办高校 思想政治工作探索与实践——建东职业 技术学院创新育人模式为例[J].当代教育 实践与教学研究,2019,(17):190-191. 
具体问题具体分析的原则选择训练项目, 保证项目选择的科学合理, 有效避免跟 风选择或盲目选择的情况发生。

\section{2 合理变化训练周期}

与其他阶段的田径体育训练不同, 中学体育田径训练面对的教育群体是中 学生, 是一个生理和心理正处于发育关 键时刻的一个年轻群体。所以, 中学体育 田径训练在实际开展的过程中, 必须结 合中学生身体发育的实际需求, 对训练 周期进行合理调整。对于中学生来说, 早上的训练时间是最合适的, 因为早上 训练完成后, 学生的精力可以更加充沛, 另外, 早上的时间学生的记忆能力相对 较好, 学生能够更加牢固的理解并掌握 田径体育训练项目内容及技能, 有效激 发学生一整天的学习热情。除训练时间 之外, 休息时间以及休息时间的长短也 应当作为训练周期考虑的内容。

2. 3 适度调整训练强度
与专业的国家运动员训练内容不同, 中学体育田径训练的强度不宜过高, 这 是因为对于中学生群体来说, 过强的训 练强度可能会起到适得其反的作用, 不 仅出现损伤学生身体的情况, 而且会打 消学生的热情, 所以科学合理的训练强 度对提高中学田径体育训练效果具有重 要影响, 应结合具体情况适时调整。学生 的身体素质、爱好以及特长等因素都应 在训练强度制定过程中加以考虑, 综合 学生们整体的情况, 制定相应的合理的 训练强度, 如果学生对于当前训练强度 出现不适, 应及时调整训练强度, 以学生 的身体发育情况作为训练强度调整的依 据, 同时有效保障田径体育训练项目的 正常开展。

\section{3 结束语}

作为中学体育教学的重要内容之一, 田径体育训练的意义十分重大, 也是学 生体育教育的必要环节, 但当前国内中
学田径训练依然存在许多问题, 严重影 响我国学生体育教育未来的发展, 为解 决这些问题, 必须尽快实行中学体育田 径训练的改革, 但是众多不可控因素对 改革影响重大, 所以体育改革可当科学 合理, 避免盲目跟风。任课教师应当认识 到中学田径体育训练对中学生体质的重 要作用, 通过制定科学合理的训练方案, 有效提高学生整体的身体健康水平, 激 发学生的学习兴趣, 进而提升中学田径 体育训练的最终效果。

\section{[参考文献]}

[1]顾华华.试论中学田径体育训练 现状及改革创新对策 [J]. 当代体育科 技,2017,7(05):47-48.

[2]范晓东.中学体育田径业余训练的 方法[J].当代体育科技,2017,7(2):54-55.

[3]张亚辉.太原市重点中学田径训 练现状与对策研究[D].山西大学,2016. 